\title{
Strong Relationship between Dry-Season Rainfall over West Africa and Extratropical Disturbance
}

\author{
Ewanlen Inegbenoise Rufus and Adeyeye Joseph \\ Department of Water Resources \& Agro-Meteorology, Federal University Oye-Ekiti, P.M.B. 373, Ekiti 0100, Nigeria
}

\begin{abstract}
The recent concerns for food security over Africa related to several climatic factors, such as the strength of the flood and drought within the growing and harvesting seasons and the long-term rainfall variability have motivated the study of identifying the extratropical causes of "anomalous" dry-season precipitation for the region. The paper examines the role of upper level disturbance in the unusual rainfall over the tropical region of West Africa in the dry-season for the month of December, 2014. The rainfall is examined using the GPCP (global precipitation climatology project) merged satellite-gauge daily precipitation estimate and station rain-gauge measurements obtained from Nigeria Meteorological Agency. While the atmospheric circulation features are determined by using the NCEP-NCAR (National Centers for Environmental Prediction-National Center for Atmospheric Research) reanalysis dataset, composites of NCEP/NCAR Reanalysis wind fields, pressure, temperature, humidity and moisture fluxes suggest that rainfall event that affected few countries (Nigeria, Ghana \& Cote d'Ivoire) during the period is linked with an enhanced on-shore westerly low-level flow from the Gulf of Guinea into inland, northward displacement of ITD (Inter-Tropical Discontinuity), intensification of the weak dry-season Sahara heat-low and upper-cyclonic vortex which help the generating of convection over the region. The influence of synoptic systems was also evident in the rainfall analysis for December, 2014. During the periods of study, the observed low-level flow over West Africa is likely to be an important contributor to the observed dry-season heavy rainfall, regulated by extra-tropical synoptic scale disturbances. The results provide an important basis for further studies on several cases over the past decade years producing heavy rainfall exceeding some kind of climatological, statistically-based threshold.
\end{abstract}

Key words: ITD, upper-level disturbance, precipitation, tropical region.

\section{Introduction}

The main feature in the climate of the West Africa region is the meridional oscillation of the ITD (Inter-Tropical Discontinuity) and can be divided into two seasons; rainy season and dry season. The rainy season appears from May to October and the dry season from November to April. The largest part of the annual precipitation falling during the boreal summer, when moist southwesterlies flow are the dominant features over the continent in response to the intense thermal low over the Sahara (Hamilton and Archbold 1945; Griffiths 1972a; Leroux 1983a; Buckle 1996; Leroux 2001; Fink et al. 2007). During the dry season the ITD is at its south-most location while the dusty and dry harmattan winds from the

Corresponding author: Ewanlen Inegbenoise Rufus, Dr., research fields: atmospheric circulation and precipitation.
Sahara dominate the dynamics of the atmosphere and rainfall is practically absent to the north coastal region of West Africa. Sometimes the dry season is interfered by rainfall with significant impact on the social and economic conditions of the region (Fig. 1), for example Nigeria, Togo, Ghana and Cote d'Ivoire. The rainfall amount during the period of 18-21 December 2014 for the study area (Fig. 2), many stations had rain with value greater than $30 \mathrm{~mm}$. As noted by Knippertz and Fink (2008, 2006), the unusual dry season rainfalls over West Africa unveiled a close link to synoptic evolution of extratropics, with emphasis on the role played by upper level troughs in the tropical region and the moisture transport associated with the TP (tropical plumes) during the boreal cool and transition seasons. The accompanying bands of mid- and high-level clouds extending from the tropics to subtropics (shown in Fig. 3) are known as TP 


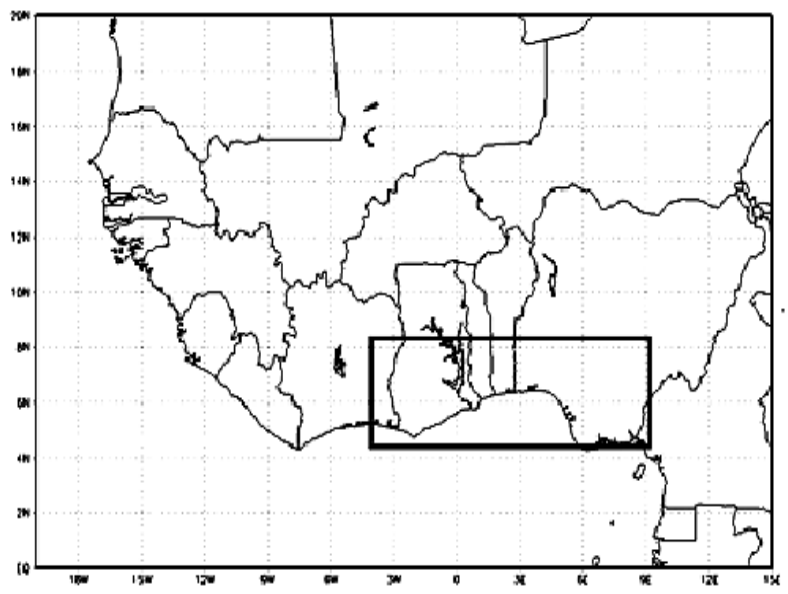

Fig. 1 The map of West Africa region as defined by latitude $5^{\circ}-20^{\circ} \mathrm{N}$ and longitude $17^{\circ} \mathrm{W}-10^{\circ} \mathrm{E}$. Gray box marks the study area.

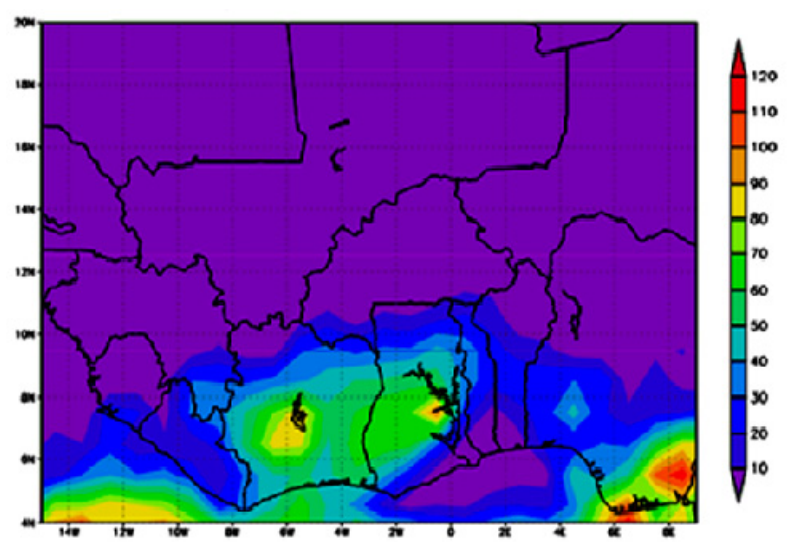

Fig. 2 The GPCP-accumulated rainfall $(\mathrm{mm})$, shading depicts rainfall amount $(\mathrm{mm})$ according to scale at the side for 18-21 December 2014 over longitude $10^{\circ} \mathrm{E}-18^{\circ} \mathrm{W}$ and latitude $4^{\circ}-8^{\circ} \mathrm{N}$ of West Africa.

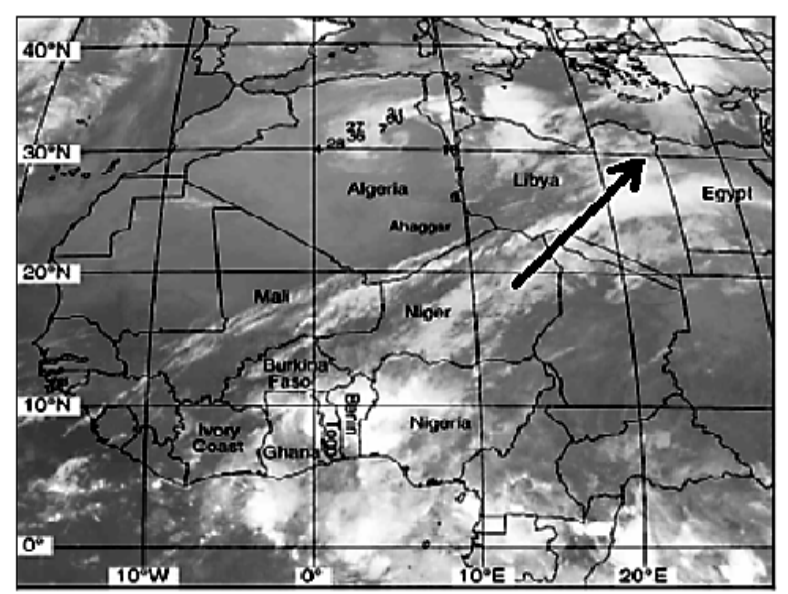

Fig. 3 Example of satellite IR imagery (Meteosat) for 2300 UTC 20 Jan. 2004, showing a TP that extends from West Africa toward the eastern Mediterranean. The black thick arrow indicates the TP (Knippertz, and Fink, 2008).
(McGuirk et al. 1988; Knippertz 2004). Various approaches have described the different mechanisms involved in the tropical and extratropical interaction (Alexandra 2010; Liu et al. 2004; Repelli and Nobre 2004; Kushnir et al. 2006) concentrated on the use of SST (sea-surface temperature) variability and the decadal oscillation. This paper therefore describes the influence of the extratropical upper level disturbance on the unusual rainfall during the dry-season over West Africa in December 2014. Analysis of wind field, moisture and rainfall variables in the study area is performed with a view to determine the typical large scale circulation patterns during the dry-season rainfall. Attempt is also made to depict features which may be distinctive of extratropical and tropical interactions relating to the occurrence of the unusual dry-season rainfall over West Africa. In the following, Section 2 describes the data and methods for the analysis. The major section of this paper presents the results and discussions related to the role of extratropical upper level disturbance in the unusual dry-season rainfall over West Africa. The last section includes the summary and conclusions of this study.

\section{Data and Methods}

\subsection{Data}

The GPCP (Global Precipitation Climatology Project) dataset (Xie et al. 2003). The GPCP precipitation analysis is defined by merging several types of observation-based individual datasets such as the gauge observations and estimates inferred from infrared satellite observations of outgoing long wave radiation, and the SSM (special sensor microwave) with spatial resolution of $2.5^{\circ} \times 2.5^{\circ}$. The pentad, daily and monthly data for 1979-present are generated by the model. The quality and accuracy of the GPCP data is found to be an improvement compared to other precipitation gridded data. The period investigated here is the dry-season month of December, 2014.

The NCEP (National Centers for Environmental Prediction) reanalysis data (Kalnay et al. 1996; Kistler 
et al. 2001). The reanalysis data are generated by a GCM, but relaxed to existing available observation data. By this analysis method the observation data are incorporated into a gridded global field, generally available at a resolution of $2.5^{\circ} \times 2.5^{\circ}$. The reanalysis data confidence is generally dependent on two factors. The first factor is the coverage of observation data available. The confidence in the reanalysis fields is therefore largest where the observational coverage is best. While in areas of more sparse observations there might be some biases in the reanalysis fields (e.g. the West Africa region). The number of available observations has also changed over the reanalysis period. This can also be due to the biases introduced to some extent in certain periods of the reanalysis. The different fields that are produced by the reanalysis are all grouped into three different levels of confidence (Kistler et al. 2001). The first confidence level includes the fields where the incorporated observations have a strong influence on the reanalysis data. Such fields are wind components and temperature on pressure levels and surface pressure. The second confidence level includes the fields where the observed values have a large influence, but where the model also has a large degree of influence. Example of such a field is the humidity on pressure levels. The confidence of the fields of the two first levels in the reanalysis is relatively good. The third level includes fields such as precipitation, evaporation and river runoff. Although reanalysis cannot be treated as pure observations, some fields like wind velocity and air temperature used for validation are strongly constrained by observed data (Kalnay et al. 1996), and they provide a validation opportunity in data-sparse regions such as West Africa. Observation data for 60 of these fields are not included into the reanalysis; they depend on the model and its parameterizations. The large-scale patterns of these fields are found to compare well to observed values, while substantial differences are evident on regional scales (Janowiak et al. 1998). The reanalysis is available as 6-hourly data for the period from 1948 until present and is available from ftp.cdc.noaa.gov. Data from the NCEP/NCAR reanalysis in December, 2014 are used in this work.

\subsection{Method}

The dry-season period between 18-21 December 2014 , over the region is analyzed by using directly NCEP reanalysis data for MSLP (mean sea level pressure), wind fields, moisture field, geopotential height and precipitable water at 1000-200 hPa levels. While the relative vorticity at isentropic level $345 \mathrm{~K}$ and specific humidity at $300 \mathrm{~K}$ are computed by using FORTRAN based on NCEP data. Daily rainfall analysis is based on observational and gridded GPCP data. Details of the methodology are described by Huffman et al. (1995). The software of GrADS (Grid Analysis and Display System; Doty 1997) is used for processing and graphical visualization of all the results.

\section{Results \& Discussions}

The rainfall events selected for investigation occur between 18-21 December 2014. Rainfall amount, greater than $30 \mathrm{~mm}$ of precipitation is recorded during the dry season over most coastal parts of the tropical region of West Africa, with a maximum of $80 \mathrm{~mm}$ (in Nigeria, $4^{\circ}-6^{\circ} \mathrm{N}, 6^{\circ}-9^{\circ} \mathrm{E}$ and Cote d'Ivoire, $6^{\circ}-8^{\circ} \mathrm{N}$, $5^{\circ}-7^{\circ} \mathrm{W}$; see Fig. 2). The atmospheric circulation types involving with the rainfall events in the region are dynamically analyzed by considering the geopotential height, local pressure, $200 \mathrm{hPa}$ levels wind components and the $345 \mathrm{~K}$ isentropic level relative vorticity, as well as the moisture transports and streamlines at 925-850 $\mathrm{hPa}$ level.

\subsection{The Regional Atmospheric Circulation}

Figs. 4 and 5 show the $925 \mathrm{hPa}$ winds, MSLP \& precipitable water at 1200 UTC over West Africa during 18-21 December 2014. We observe that on 18 December, before the rainfall begins, weak MSLP gradients and light southerly winds prevail across coastal area of West Africa (Fig. 4a). Also, easterlies 
winds from Saharan origin are evident over the domain. These easterlies dry and dusty winds are the result of the pressure gradient between the subtropical anticyclone centered around $30^{\circ} \mathrm{N}$ and the weak continental heat low, usually located just to the north of the guinea coast at $7^{\circ}-8^{\circ} \mathrm{N}$. The narrow, more or less east-west oriented zone between two air masses, the Saharan air and the moist south-westerlies air is called the ITD (Sultan et al. 2001; Ilesanmi 1971). It is the location of the surface position of the ITD that controls the West African rainfall season. On 19 December 2014, the ITD is displaced north over the region that is affected by the rainfalls on 21 December (Fig. 4b). Southwesterly winds dominate the south of the ITD. A day later, on 20 December, the MSLP distribution has changed considerably with a now
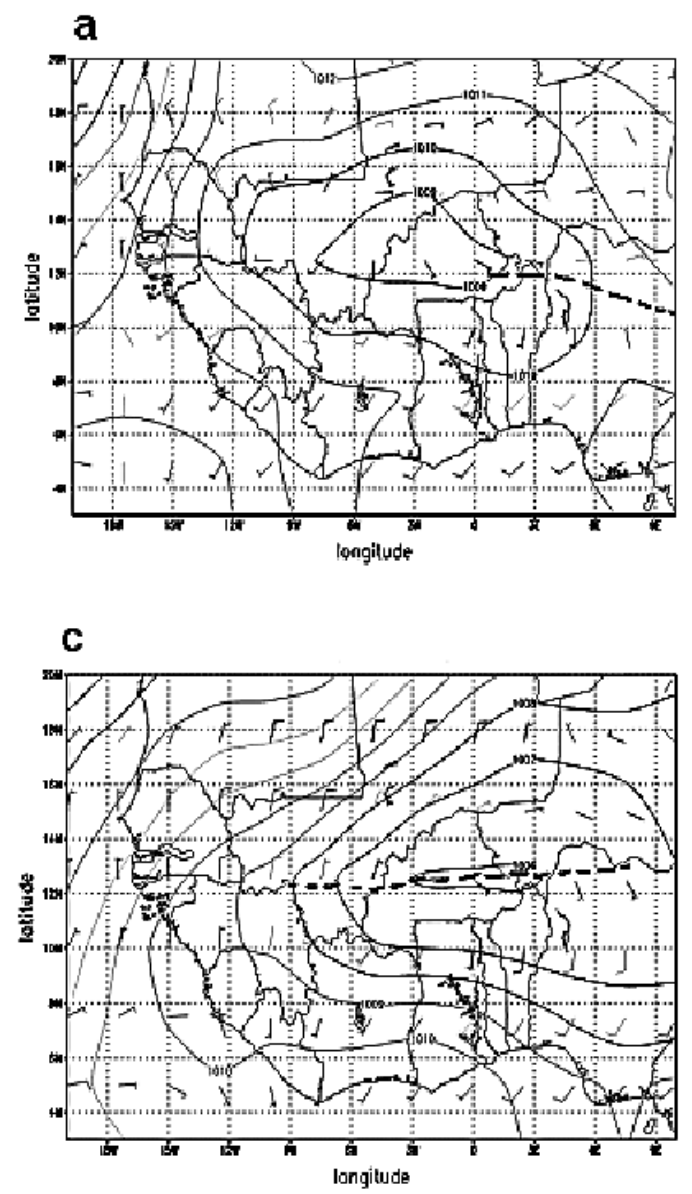

clearly display minimum of $1006 \mathrm{hPa}$ center over Niamey (Fig. 4c). In this region, the pressure has fallen by $2 \mathrm{hPa}$. Wind observations reflect the cyclonic circulation around the low center with a southerly component reaching up to $12^{\circ} \mathrm{N}$ over Benin, Togo, Ghana, Burkina Faso and Nigeria (Fig. 4d). This flow brings moist south-westerlies air much farther into the continent that is unusual (Fig. 6), as demonstrated by the change in humidity (see Fig. 14a) and in the position of the ITD, respectively. Also, the precipitable water over central Ghana \& Nigeria increases to $40 \mathrm{~mm}$ (Fig. 5d) during the period.

Observations over Mali and Niger, that is, to the north of the area, reveal falling MSLP over most of the period from 18 to 21 December 2014 (shown in Figs. 4a-4c). While the pressure fall is slow, but

b

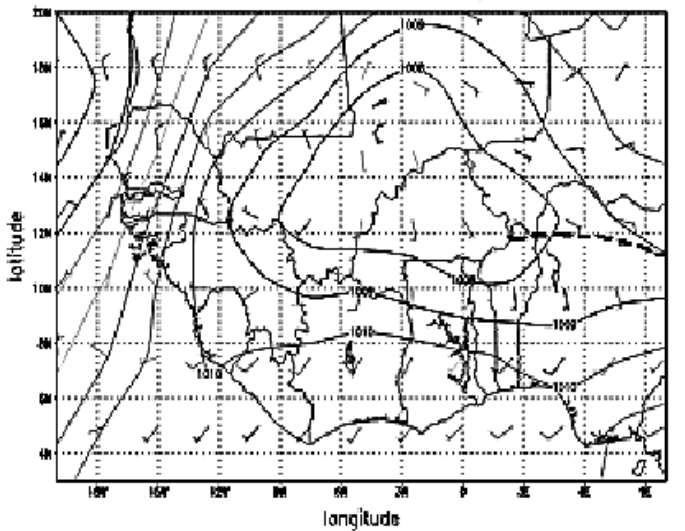

d

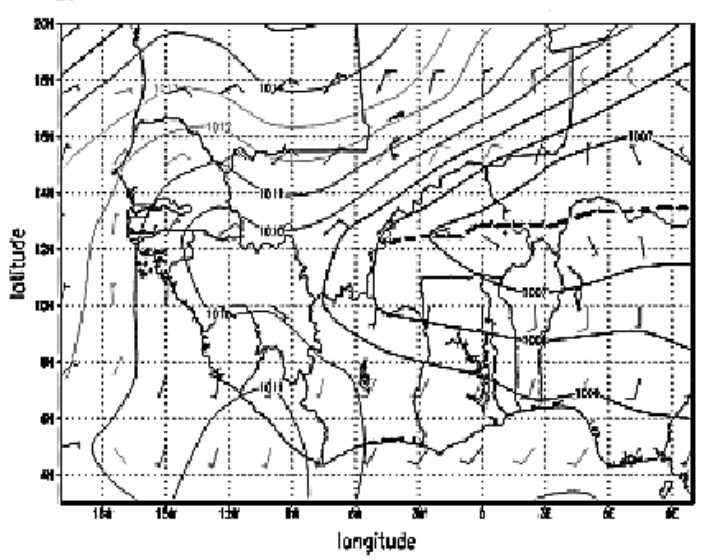

Fig. 4 Synoptic features over West Africa for (a) 18 December, (b) 19 December, (c) 20 December and (d) 21 December 2014. The solid lines indicate MSLP contoured every $1 \mathrm{hPa}$ and the $925 \mathrm{hPa}$ wind shown as barbs. The ITD is marked by thick dashed line. 
a

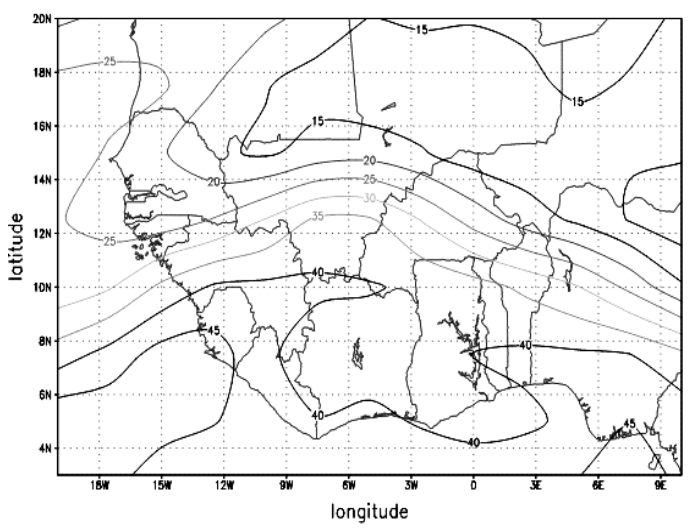

C

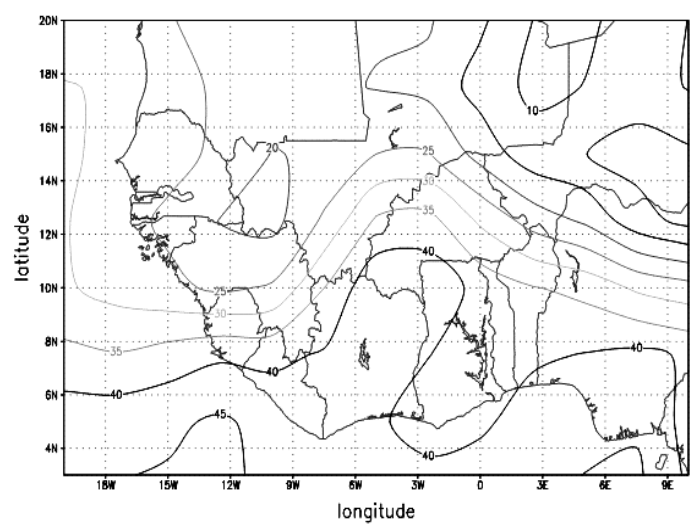

b

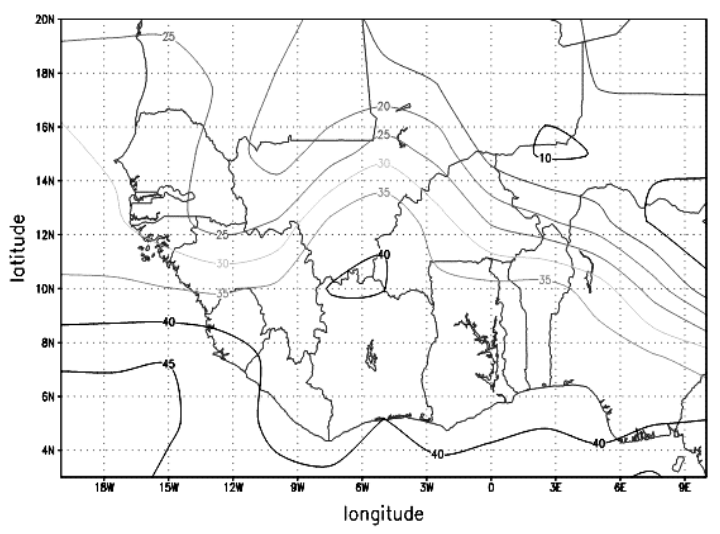

d

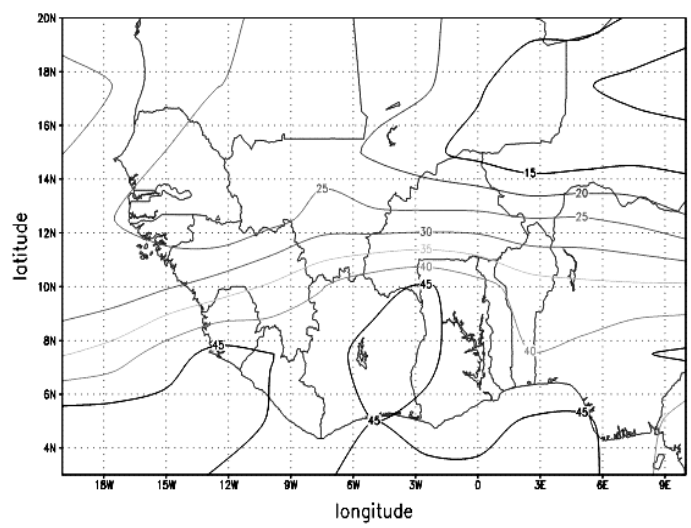

Fig. 5 The precipitable water distribution (mm) for (a) 18 December, (b) 19 December, (c) 20 December and (d) 21 December 2014 over West Africa.

continuous during 18-20 December, a quite pronounced drop is identified on 20 December followed by an equally distinct rise over the course of 21 December. This change is best seen at 1800 UTC, the time with the strongest heat low effect. The presented observations show that the intensification and the north-westward shift of the weak dry-season heat low (see Fig. 9) has allowed an unusual northward penetration of the monsoon layer, ultimately the prerequisite for the strong rainfalls on 21 December examines this development in the context of the large-scale atmospheric circulation in the previous days over Northern Africa.

\subsection{Large-Scale Circulation}

The circulation features are dominated by an upper level trough over North Africa, weak MSLP over Sahara and the northward displacement of low-level moisture over West Africa. Composite analysis in 500 hPa geopotential-height, MSLP, humidity, surface temperature, isotach, isobar, vertical velocity and vorticity are presented in composite maps and profiles. Only 1200, 1800 and 0000 UTC values of the variable are considered for the analysis. On 18 December, the MSLP distribution shows a typical zonal structure with a relatively strong gradient between the North Africa high pressure and the low-pressure trough, with the ITD just to the north of the guinea coast (Fig. 7a). There was a weak upper-level trough over the west coast of West Africa. On 19 December, the upper trough over the west coast intensified, and the northward excursion of the ITD in Fig. $7 b$ is most 

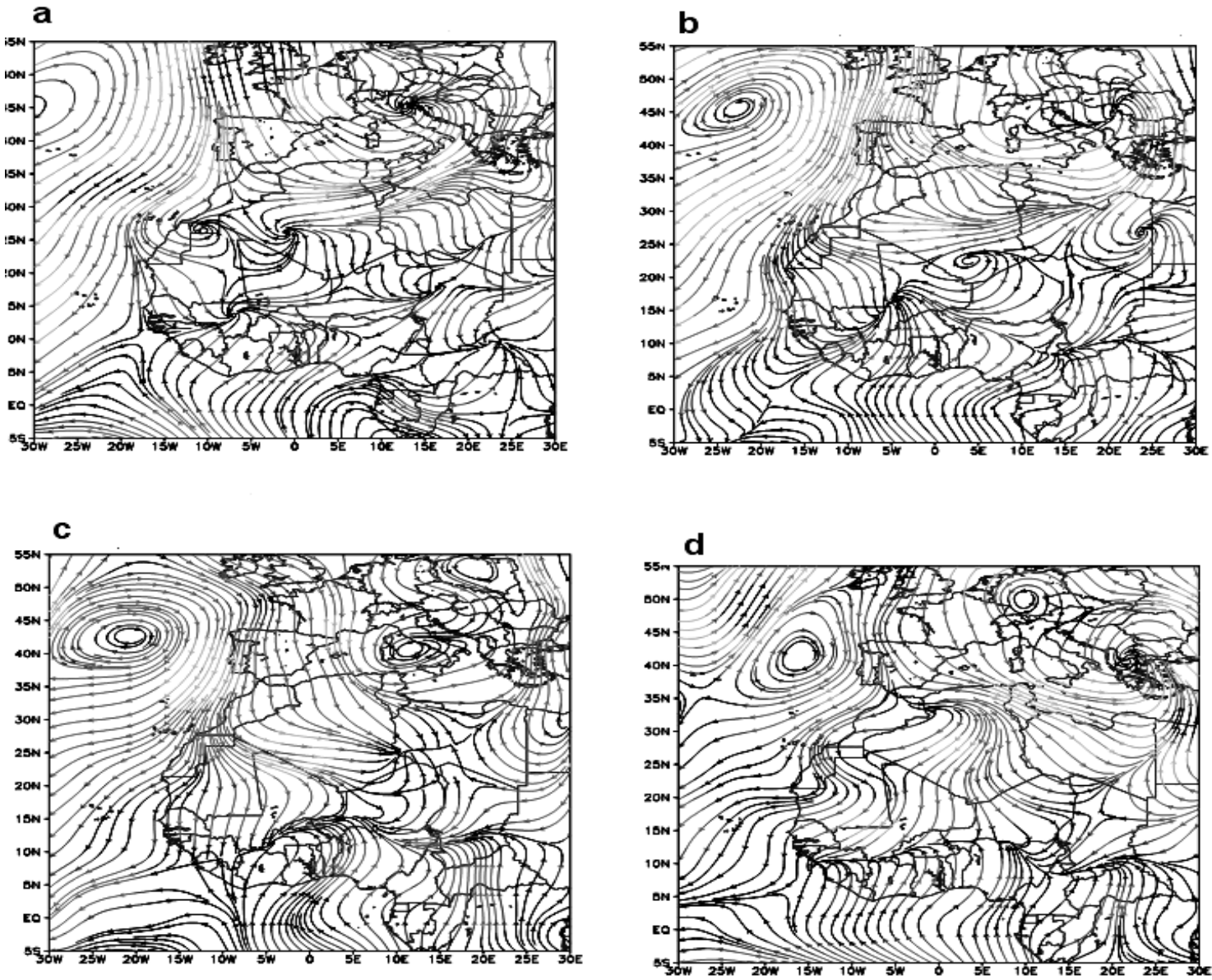

Fig. 6 Composite maps of streamlines at 925 hPa for (a) 18 December, (b) 19 December, (c) 20 December and (d) 21 December 2014 over West Africa.

likely the result of this pressure fall and the subsequent deeper penetration of southerlies winds over the continent. Fig. 8 shows that the pressure fall is connected to the heating of the atmospheric vertical structure caused by locally enhanced greenhouse effect due to higher water vapour content in the region.

On 19 December, the upper level trough continues to move eastward across West Africa (Fig. 7c), bringing precipitation to parts of Nigeria, Ghana and Cote d'Iovire. The MSLP fell over large parts of the Sahel, consistent with the station observations (not shown). Over the next days the trough remained almost stationary. A slight northward shift of the ITD can also be observed. A pronounced upper trough begins to penetrate into Libya from the western Mediterranean Sea (Fig. 7c). It is associated with low MSLP in a band from western Libya to Valletta. On

20 December, this trough merges with the one over West Africa forming a large system with a strongly tilted horizontal axis (Fig. 7d). To the trough axis southeast, MSLP is observed to decrease over a large area, leading to the northward displacement of the heat low and the ITD (shown in Fig. 9).

Finally, on 21 December the upper-level trough center over Malta with a minimum geopotential height of about 5,400 gpm, while the surface depression has deepened to $990 \mathrm{hPa}$ and moved to eastern Libya (Fig. 7d). To the southeast of the trough, the MSLP falls become quasi-stationary and enhance southerly moisture advection into the continent that allow the generation of deep convection for the unusual rainfall (see Fig. 2). It is discernible that low inertial instability (see Fig. 13) along the flank of anticyclone of the STJ (subtropical jet) streak, associated with the 

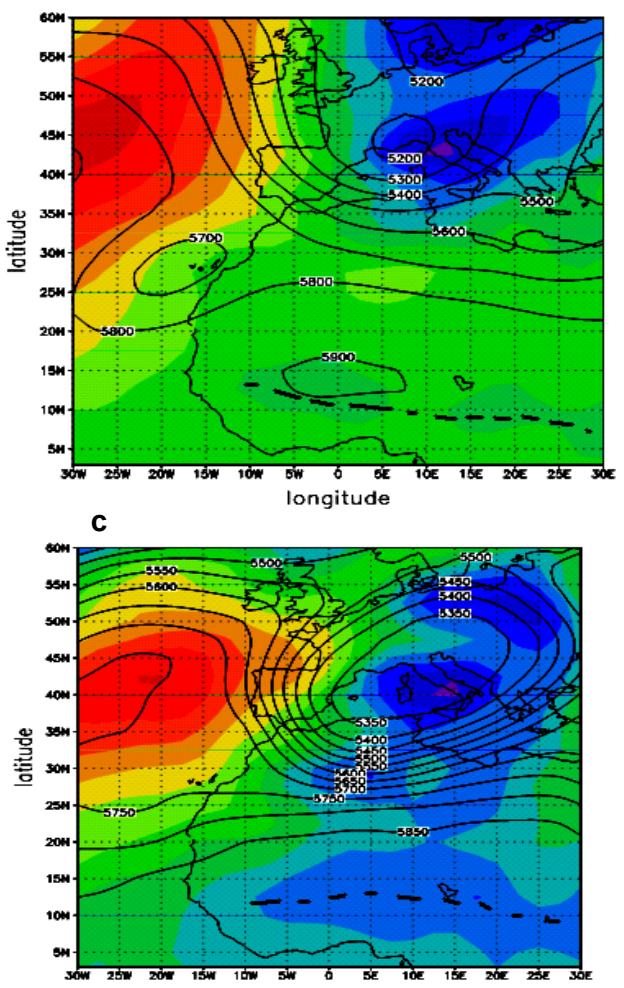

b
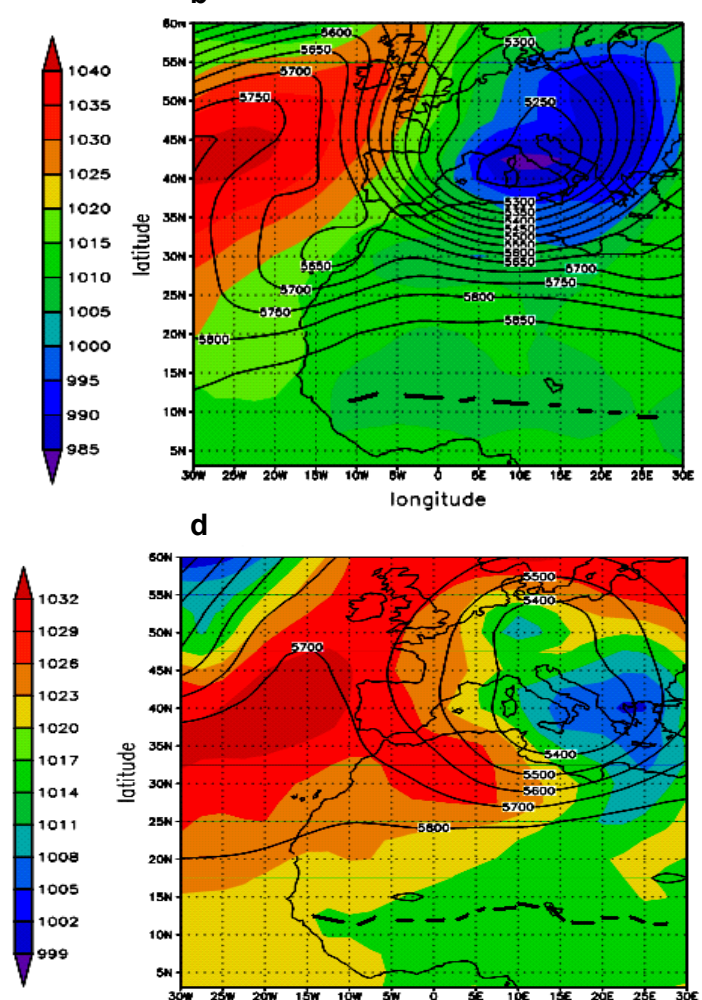

d
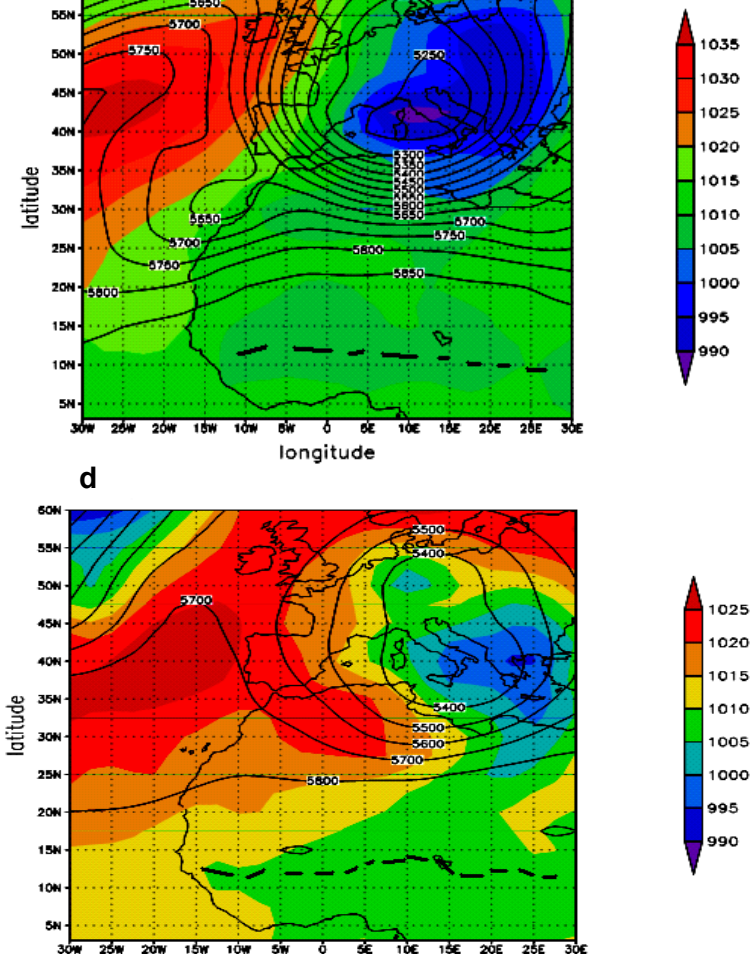

Fig. 7 Map of $500 \mathrm{hPa}$ geopotential height (contour), shading depicts MSLP according to scale at the side and the ITD (black dot-dashed lines) for (a) 18 December, (b) 19 December, (c) 20 December and (d) 21 December 2014 over West Africa.

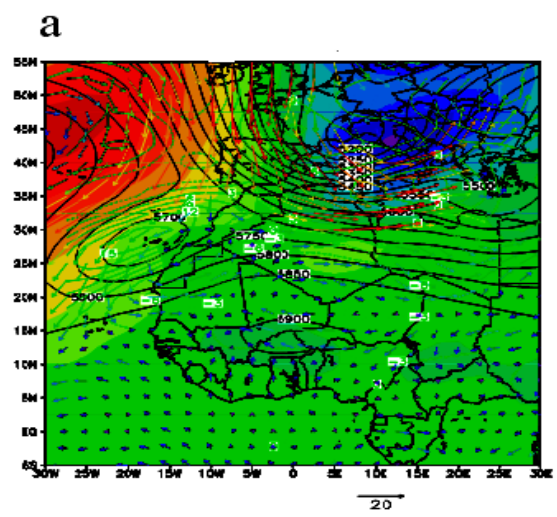

$\mathrm{c}$

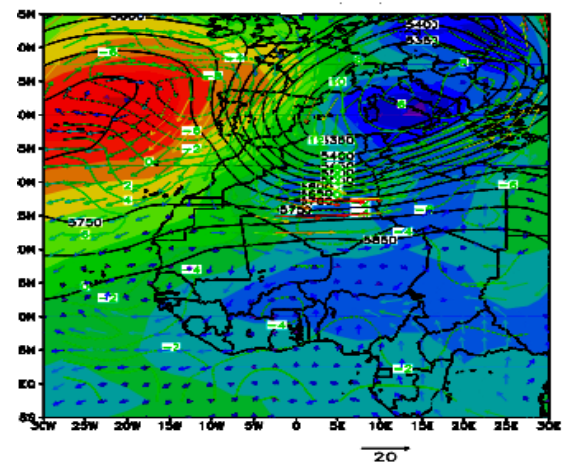

b

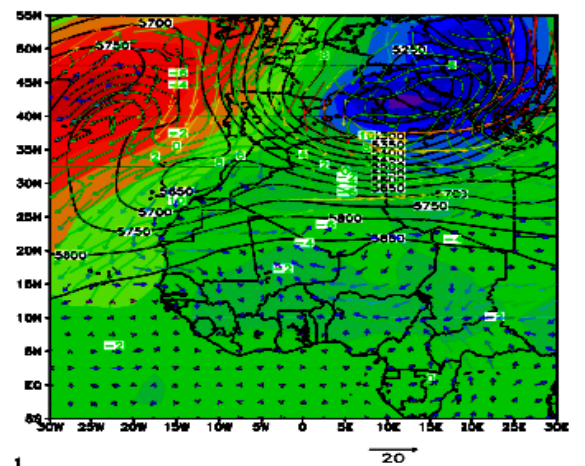

d

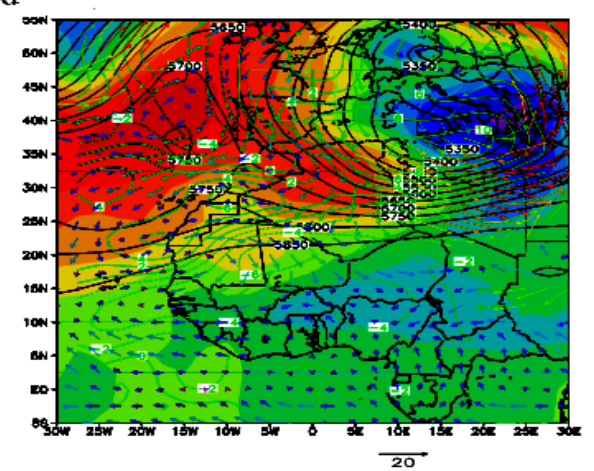

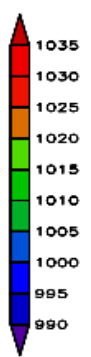

1026
1023
1020
1017
1014
1011
1008
1005
1002
999
998

Fig. 8 Mean sea level pressure field (shaded in hPa), $500 \mathrm{hPa}$ geopotential height (solid contours in gpm) and horizontal wind vectors at 850 hPa for (a) 18 December, (b) 19 December, (c) 20 December and (d) 21 December 2014 over West Africa. 
a
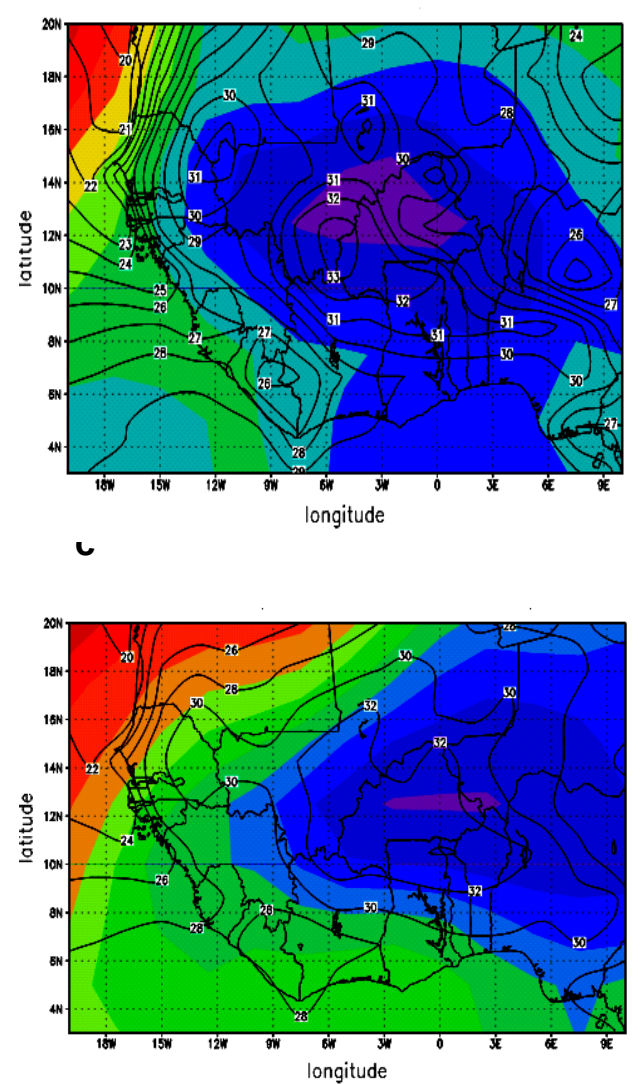

b

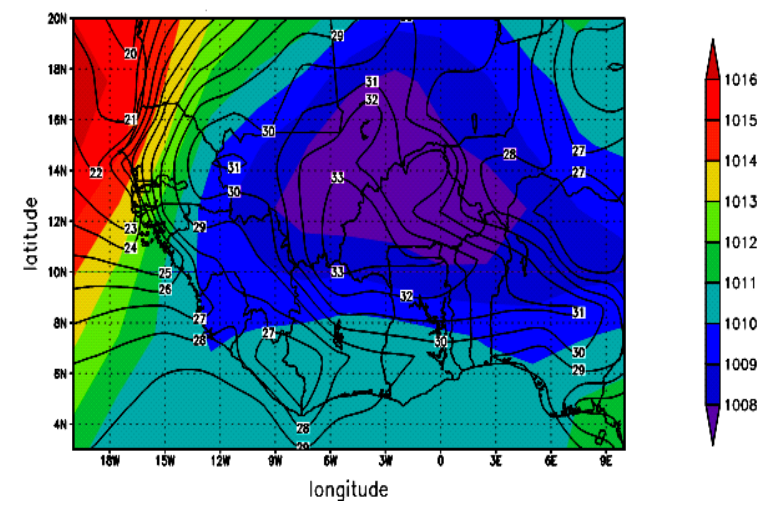

d

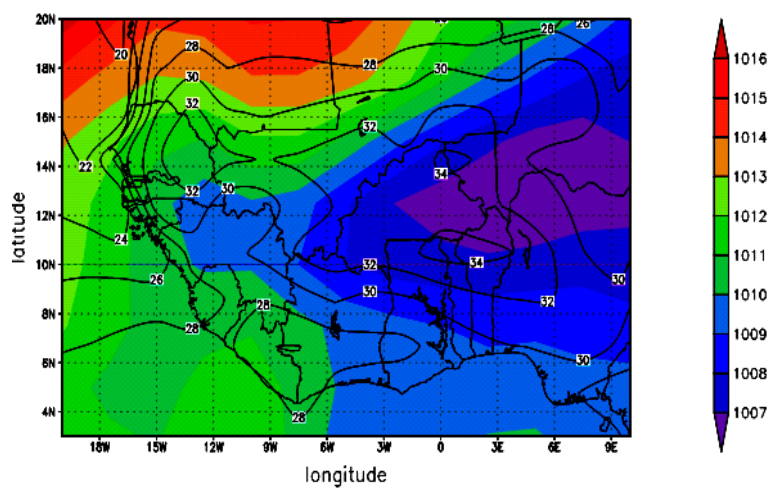

Fig. 9 Daily surface temperature (contour) \& shading depicts MSLP according to scale at the side for (a) 18 December, (b) 19 December, (c) 20 December and (d) 21 December 2014 over West Africa.

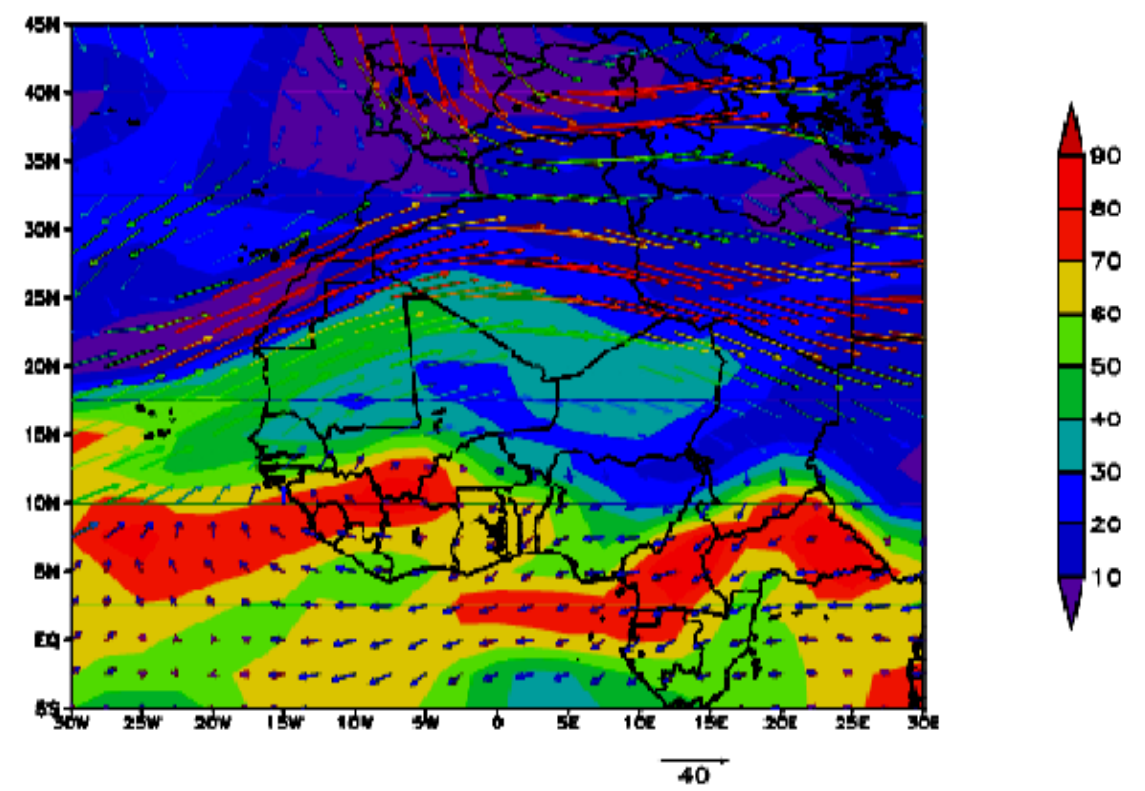

Fig. 10 Composite map of meridional specific humidity transport $\left(10 \mathrm{~g} \cdot \mathrm{kg}^{-1} \cdot \mathrm{m}^{-\mathrm{s}^{-1}}\right.$ increments, shaded) \& wind vector on $310 \mathrm{~K}$ isentropic surface for 18-21 December 2014. 


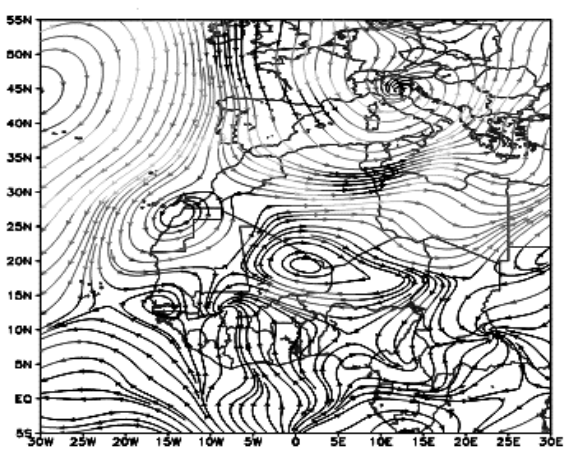

C

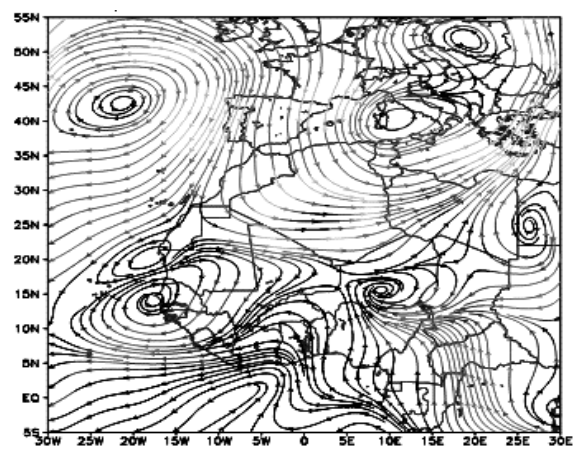

b

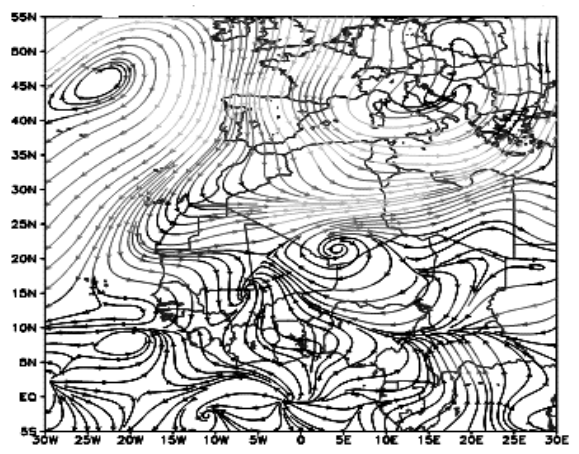

d

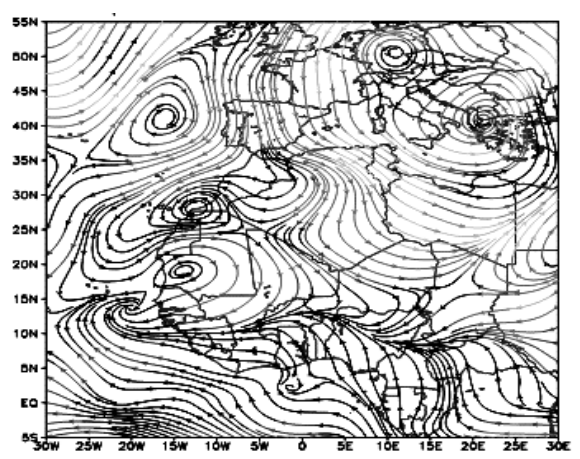

Fig. 11 Composite maps of streamlines at $850 \mathrm{hPa}$ associated with the dry season rainfall for (a) 18 December, (b) 19 December, (c) 20 December and (d) 21 December 2014 over West Africa.

a

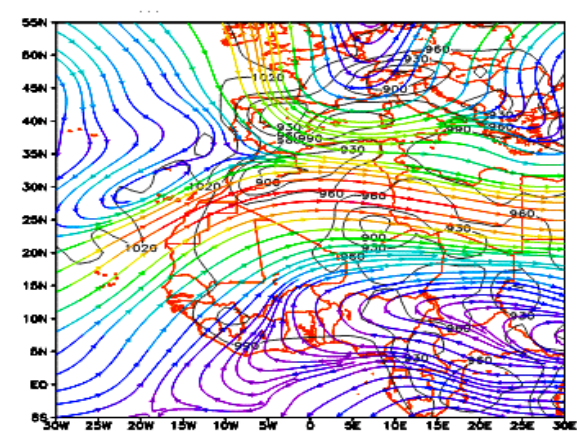

C

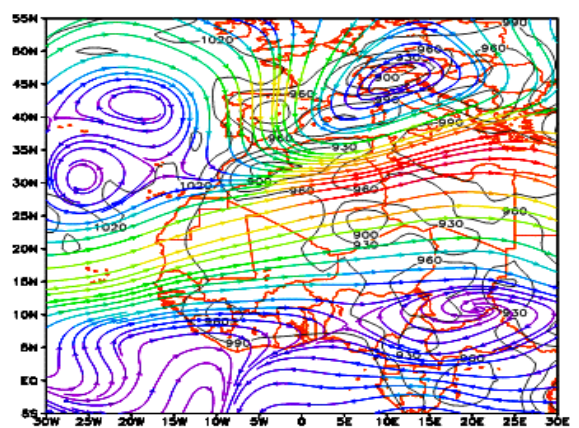

b

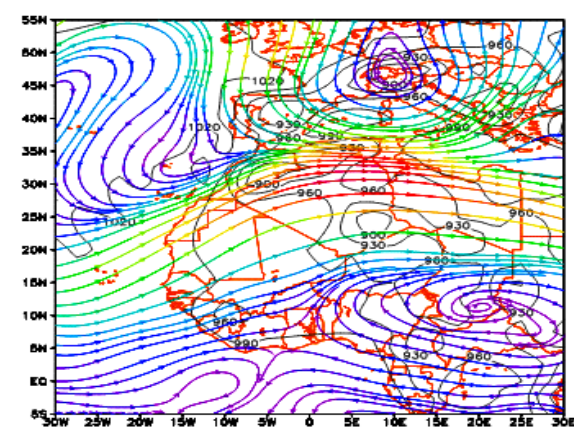

d

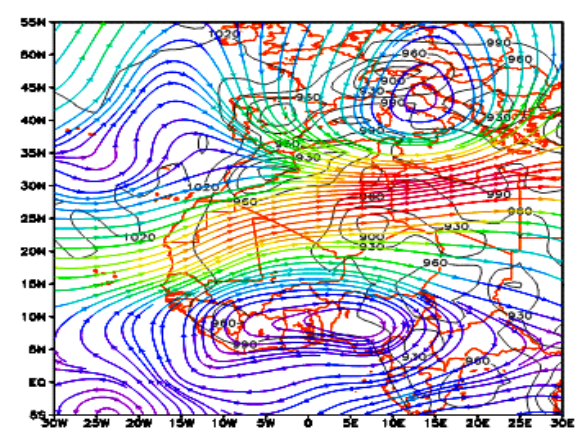

Fig. 12 Isobars (gray in hPa) and streamlines at $300 \mathrm{~K}$ isentropic surface for (a) 18 December, (b) 19 December, (c) 20 December and (d) 21 December 2014 over West Africa. 
a

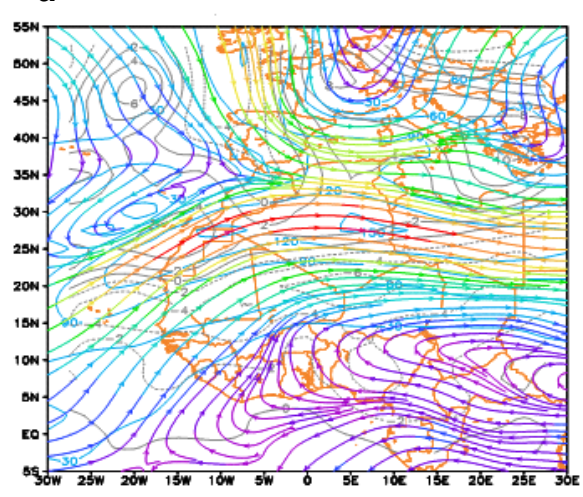

C

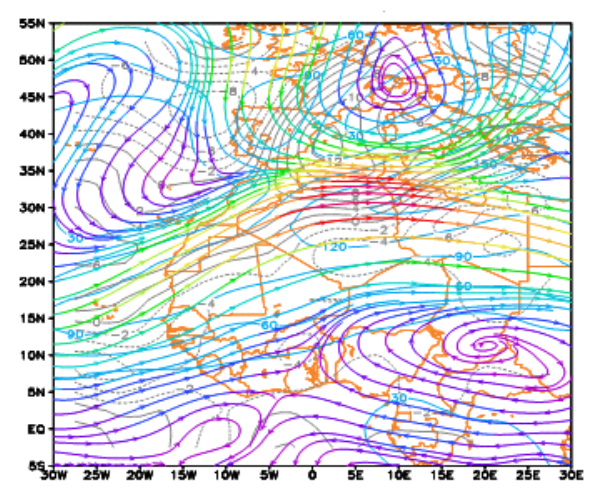

b

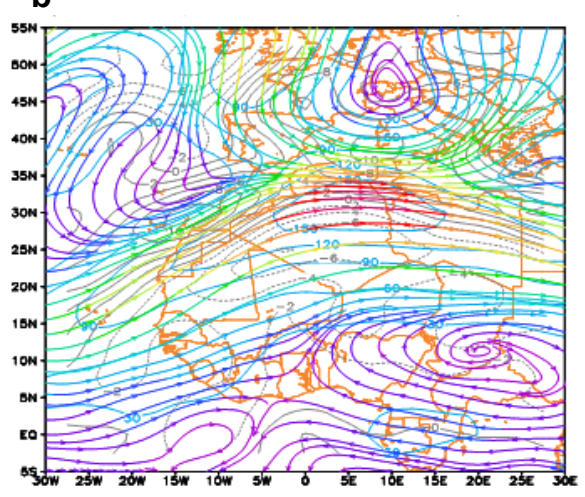

d

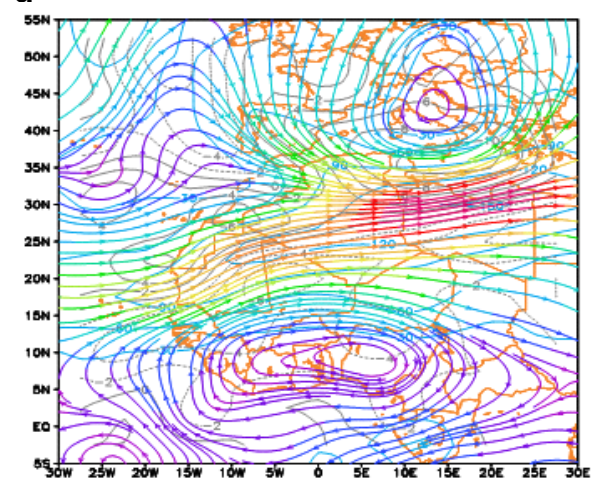

Fig. 13 Streamlines, $200 \mathrm{hPa}$ relative vorticity (filled gray contours in $10^{-5} \mathrm{~s}^{-1}$; Solid and dot-dashed lines indicate positive and negative vorticity, respectively) and isotachs (blue, $\mathrm{m} / \mathrm{s}$ ) at $330 \mathrm{~K}$ isentropic surface for (a) 18 December, (b) 19 December, (c) 20 December and (d) 21 December 2014 over West Africa.

upper trough has provided good outflow conditions for the convection.

\subsection{Dry-Season Heat Low}

Daily zonal temperature analysis between 18-21 December 2014 reveals unusually hot temperatures over Niamey and neighboring countries (Fig. 9). The month of December shows temperature observations of up to $300 \mathrm{~K}$ in this region (Fig. 9d) and some stations recorded maxima of more than $310 \mathrm{~K}$ on that day (not shown). The hot temperatures were accompanied by unusually low MSLPs that fell to $1005 \mathrm{hPa}$ in the afternoon of 20 December (see Fig. $9 \mathrm{c})$. The associated cyclonic circulation is evident in the low-level winds (Figs. 6 and 11). To the southeast of the intensified heat low, southwesterlies winds dominate over Nigeria, Benin, Togo and Ghana that bring relatively moist air over the continent, similar to spring or fall situations. This circulation causes the ITD to migrate northward, which is observed on 17 December to be close to its climatological position just to the north of the Guinea Coast at about $7^{\circ} \mathrm{N}$ (not shown). Until 20-21 December the ITD slowly moves northward and reaches a very unusual northerly position of $13^{\circ} \mathrm{N}$ (Fig. 4b). These observations indicate a progressive intensification and northward shift of the heat low associated with an unusual pole ward penetration of moist, monsoonal air into the continent prior to the precipitation event.

\subsection{Upper Level Disturbance}

The unusual behaviour of the heat low is connected with the intrusion of an upper-level trough from the extra tropics to low latitudes over North Africa (see Fig. 7d). Since the upper-level synoptic situation during this case is rather quasi-stationary in the 
subtropics, we examine episode means (18-21 December 2014) of different atmospheric parameters instead of the characteristic single dates as for the other cases. Figs. 12a-12d show mean streamline and isobars at the $300 \mathrm{~K}$ isentropic surface for 18-21 December 2014. A well-defined upper-level subtropical trough remained quasi-stationary over the Atlantic West of North Africa through the period. Average wind speeds reach $40 \mathrm{~m} / \mathrm{s}$ on eastern side of the trough (Figs. 13a and 13b). An anticyclone center formed around $10^{\circ} \mathrm{N} \&$ $8^{\circ} \mathrm{E}$, which blocked tropical-extropical exchange and forced the trough to retreat northward again (see Fig. 12d). An STJ streak is located across Northern Africa (Fig. 13d), the STJ then tilt and intensify as observed to be $80 \mathrm{~m} / \mathrm{s}$ (Fig. 13d) and moved north-eastward to about $25^{\circ} \mathrm{N}, 15^{\circ} \mathrm{W}$. Clouds spread deep into region of West Africa along the equatorward position of the jet (not shown). Strong convection and the anticyclonic circulation at upper-levels are then seen over, Ghana, Togo, Ivory Coast and Nigeria. Streamlines show strong subsidence over Niger, this divergent flow is approximately at $200 \mathrm{hPa}$ (Fig. 13c).

\subsection{Rainfall Events}

An unusual rainfall occurrence in December is a

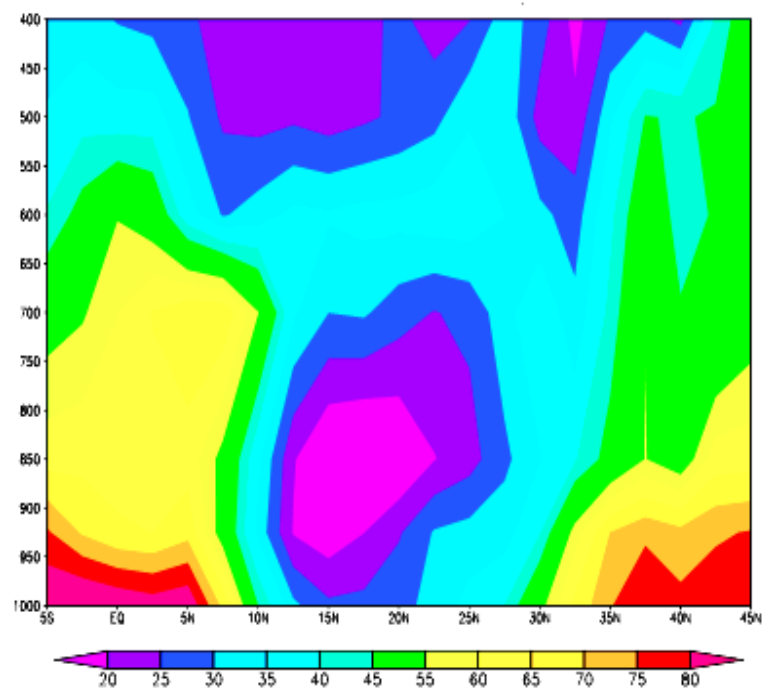

examined. The month of December is climatologically a dry-season period in tropical West Africa and the rainfall long-term average lies between 0 and $6 \mathrm{~mm}$ at north of latitude $8^{\circ} \mathrm{N}$ (WMO 1996). The GPCP data analysis shows values of $40 \mathrm{~mm}$ (Fig. 2b) in most stations except in southern Cote d'Ivoire and Nigeria with observed rainfall greater than $60 \mathrm{~mm}$, a substantial deviation from the climatology over a large region including parts of Ghana, Togo, Benin, and Nigeria. The accumulated rainfall amount for 18-21 December 2014, clearly shows that the rainfall period is characterized with high relative humidity, strong moist southerly winds and low MSLP. The analysis of specific humidity, indicates high values absolute moisture content over the region (Fig. 10). The increase moisture could be as a result of stronger vertical velocity (Fig. 14b) and TP development at mid-tropospheric level (600 hpa). Vertical profile of relative humidity (Fig. 14a) during the heavy rainfall of 21 December 2014, shows that high humidity prevails both at the lower and mid-tropospheric levels, with values exceeding $65 \%$ at $850 \mathrm{hPa}$ level and $70 \%$ above $700 \mathrm{hPa}$. The rainfall zone usually restricted to Gulf of Guinea during the dry season reached unusually far inland over the region of West Africa. It

b

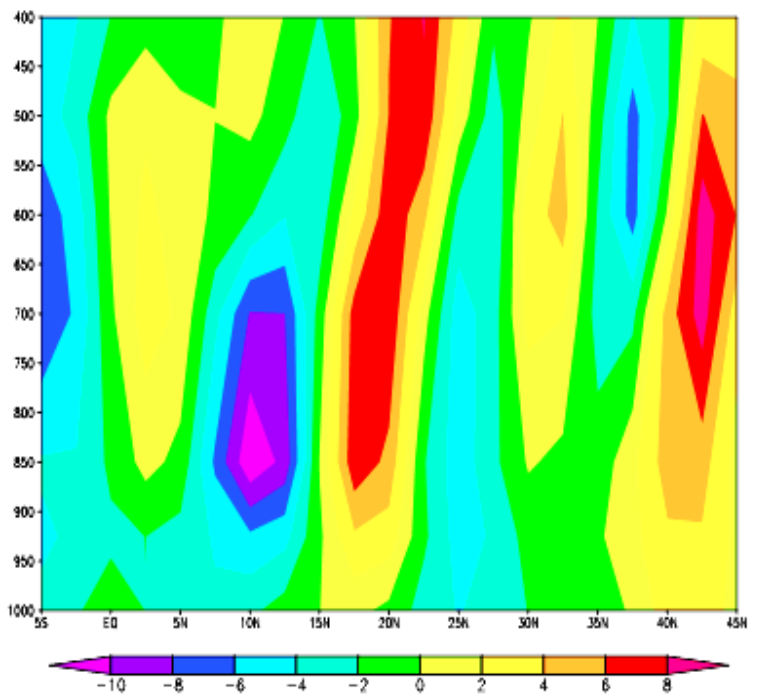

Fig. 14 Meridional cross section mean at $5^{\circ}-45^{\circ} \mathrm{N}, 30^{\circ} \mathrm{E}$ of (a) RH (\%) and (b) vertical velocity (cm $\cdot \mathrm{s}^{-1}$ ) for $1200 \mathrm{UTC} 18$ December-0000 UTC 21 December 2014. 
is important to state that, the yearly passing over of mesoscale convective clusters within the study area as seen from infrared satellite image (not shown), are usually directed by the basic flow to south-west location, such that the flow direction that is observed in this study become very abnormal. The negative-vorticity air advection from the southern hemisphere may also have contributed to the inertial instability as display by the cross-equatorial flow between $10^{\circ} \mathrm{W}$ and $20^{\circ} \mathrm{E}$ (Fig. 13). Different studies have indicated that inertial instability near the tropopause allows a quick horizontal shift of convective outflow and thereby enhance the organization and maintenance of convection (Knippertz and Martin 2005; Mecikalski and Tripoli 1998). The upper level outflow conditions on 20-21 December (Fig. 13) therefore play important roles in the generation of the rain to the south of ITD in the tropical region of West Africa.

\section{Summary and Conclusions}

The synoptic evolution and the dynamics of widespread dry-season rainfall event over tropical West Africa on December 2014 have been described in details. Results of the data analysis show good relationship between the large-scale circulation, upper-level troughs, the surface dry-season heat-low and rainfall. It is shown that advection of positive vorticity together with the high wind speeds (Fig. 13) leads to enhanced upper-tropospheric divergence. At $850 \mathrm{hPa}$, strong low-level moisture convergence maximum is observed (Fig. 11); the moisture transports into the tropical region of West Africa together with the dynamically induced ascent allow the formation of deep convective clouds that caused the observed rainfall (shown in Fig. 2). From our investigation, it is clear that the unusual rainfall that occurs over the region is initiated by the distinct upper-level disturbance in the sub-tropics and falling of the MSLP over the Sahara, which allows moist south-westerlies to penetrate further than unusual during the dry-season over the continent of West
Africa. Some factors of potential importance that are not addressed in this study are highlighted below. One is the interactions between the AEWs (African easterly waves) and the diagonal upper troughs in the westerlies in the role of precipitation generation in the dry season period of tropical West Africa (Knippertz et al. 2003). However, for December 2014 there are no indications of westward-propagating disturbances in the low-level streamlines, which is consistent with the absence of a distinct baroclinic zone over tropical region of West Africa during the dry season. The maps of surface pressure between 18 and 21 December 2014 (Fig. 12) are similar to a typical trajectory of a Soudano-Sahelian depression moving from tropical West Africa on an anticyclonic path to the Mediterranean Sea (Dubief and Queney 1935). Another factor not considered is the impact of the MJO (Madden-Julian Oscillation) on the generation of convection over West Africa (Wheeler \& Hendon 2004). Generally, it is difficult to indicate the influence of an intraseasonal variability pattern like the MJO as a localized meteorological event. Further work is therefore needed on the MJO, dynamics of Soudano-Sahelian depressions and their relation with diagonal troughs, tropical plumes, and Africa easterly waves to enable identify a typical mechanism for the dry season rainfall in West Africa associated with extra-tropical and tropical interactions.

\section{Acknowledgements}

This study is supported by NNSF Grant-41035027 and the NUIST key laboratory of meteorological disaster (Ministry of Education Project Grant KLME0908). The assistance of NUIST and NCEP, in accessing and retrieving data from their archives is also acknowledged. We appreciate the rainfall data from GPCP and Nigeria Met. Agency, Nigeria.

\section{References}

[1] Alexandra, M. 2010. "Extratropical Air-Sea Interaction, SST Variability, and the Decadal Oscillation." Climate Dynamics 189, 123-48. 
[2] Buckle, C. 1996. Weather \& Climate in Africa. Longman, p. 312.

[3] Davis, N. E. 1981. "Meteosat Looks at the General Circulation: III. Tropical-Extratropical Interactions." Weather 36: 168-73.

[4] Doty, B. E., and Coauthors. 1997. "The Grid Analysis and Display System (GrADS): An Update for 1997." In Proceedings of the 13th International Conference on IIPS for Meteorology, Oceanography and Hydrology, Amer. Meteor. Soc., Longbeach, CA, p. 117.

[5] Dubief, J., and Queney, P. 1935. "Les grands traits du climat du Sahara algérien." La Météorologie, 80-91.

[6] Fink, A. H., Kotthaus, S., and Pohle, S. 2007. "IMPETUS Atlas-Benin-Research Results, WA-B-02: Rainfall Variability in West Africa." Published by the Remote Sensing Workgroup, University of Bonn, Germany.

[7] Griffiths, J. F. 1972a. Nigeria: Climates of Africa. Edited by H. E. Landsberg, World Survey of Climatology, Vol. 10, Elsevier, 167-92.

[8] Hamilton, R. A., and Archbold, J. W. 1945. "Meteorology of Nigeria and Adjacent Territory." Quart. J. Roy. Meteor. Soc. 71: 231-64.

[9] Huffman, G. J., and Coauthors. 1995. "Global Precipitation Estimates Based on a Technique for Combining Satellite-Based Estimates, Rain Gauges Analysis, and NWP Model Precipitation Information." $J$. Clim. 8: 1284-95.

[10] Leroux, M., 1983a. Le climat de l'Afrique tropicale. Vol. 1. Champion-Slatkine, 636.

[11] Leroux, M., 2001. The Meteorology and Climate of Tropical Africa. Springer, 493.

[12] Liu, Z., Zhang, Q., and Wu, L. 2004. "Remote Impact on Tropical Atlantic Climate Variability: Statistical Assessment and Dynamic Assessment." J. Climate 17: 1529-49.

[13] Ilesanmi, O. O. 1971. "An Empirical Formulation of an ITD Rainfall Model for the Tropics: A Case Study in Nigeria." J. Appl. Meteor. 10: 882-91.

[14] Janowiak, J. 1988. "An Investigation of Interannual Variability in Africa." J. Climate 1: 240-55.

[15] Kalnay, E., and Coauthors. 1996. "The NCEP/NCAR 40-Year Reanalysis Project.” Bull Amer. Meteor. Soc. 77: 437-71.

[16] Kistler, R., and Coauthors. 2001. "The NCEP-NCAR 50-Year Reanalysis: Monthly Means CD-ROM and Documentation.” Bull. Amer. Meteor. Soc. 82: 247-67.

[17] Knippertz, P., and Fink, A. H. 2008. "Dry-Season
Precipitation in Tropical West Africa and Its Relation to Forcing from the Extratropics." Mon. Wea. Rev.

[18] Knippertz, P., and Fink, A. H. 2006. "Synoptic and Dynamic Aspects of an Extreme Springtime Saharan Dust Outbreak." Quart. J. Roy. Meteorol. Soc.

[19] Knippertz, P., and Martin, J. E. 2005. "Tropical Plumes and Extreme Precipitation in Subtropical and Tropical West Africa." Quart. J. Roy. Meteor. Soc. 131: 2337-65.

[20] Knippertz, P., and CoAuthors. 2003. "Three Late Summer/Early Autumn Cases of Tropical-Extra Tropical Interactions Causing Precipitation in Northwest Africa." Mon. Wea. Rev. 131: 116-35.

[21] Knippertz, P. 2003. "Tropical-Extratropical Interactions Causing Precipitation in Northwest Africa: Statistical Analysis and Seasonal Variations." Mon. Wea. Rev. 131: 3069-76.

[22] Kushnir, Y., Robinson, W., Chang, P., and Robertson, A. 2006. "The Physical Basis for Predicting Atlantic Sector Seasonal to Interannual Climate Variability." J. Climate 19: 5949-70.

[23] McGuirk, J. P., Thompson, A. H., and Schaefer, J. R. 1988. “An Eastern Pacific Tropical Plume." Mon. Wea. Rev. 116: 2505-21.

[24] Mecikalski, J. R., and Tripoli, G. J. 1998. "Inertial Available Kinetic Energy and the Dynamics of Tropical Plume Formation." Mon.Wea. Rev. 126: 2200-16.

[25] Repelli, C., and Nobre, P. 2004. "Statistical Prediction of Sea-Surface Temperature over the Tropical Atlantic." Int J. Climatology 24: 45-55.

[26] Sultan, B., Janicot, S., and Ramage. 2001. "Abrupt Shift of the ITCZ over West Africa and Inter-Seasonal Variability." European Geophysical Society, 26-30.

[27] Wheeler, M. C., and Hendon, H. H. 2004. "An All-Season Real-Time Multivariate MJO Index: Development of an Index for Monitoring and Prediction." Mon. Wea. Rev. 132: 1917-32.

[28] WMO. 1996. Climatological normals (CLINO) for the period 1961-1990. WMO/OMM-No. pp. 767, 847.

[29] Xie, P., and CoAuthors. 2003. "GPR Pentad Precipitation Analyses: An Experimental Dataset Based on Gauge Observations and Satellite Estimates." J. Climate 16: 2197-214.

[30] Ziv, B. 2001. "A Subtropical Rainstorm Associated with a Tropical Plume over Africa and the Middle-East." Theor. Appl. Climatol. 69: 91-102. 